\title{
Clonal variation in coppiced and uncoppiced growth, root sprout stem formation, and biomass partitioning in Salix interior on two highly disturbed site types
}

\author{
Alex Mosseler and John E. Major
}

\begin{abstract}
Salix interior Rowlee (INT) is a wide-ranging North American willow from the small taxonomic group Salix section Longifoliae, notable for its ability to form multi-stemmed vegetative stem colonies arising via root sprouts (RS) from a shallow horizontal root network. This study quantifies biomass production for both 1-year-old coppiced plants and the original 4-year-old plants established from dormant, unrooted stem cuttings, as well as for the RS stems associated with each ortet (original mother plant) using eight selected INT clones established on two distinct site types. Significantly greater coppiced and uncoppiced ortet stem dry mass was recorded on coarse-textured, shale rock overburden (SO); possibly due to significantly greater fertility, compared to adjacent gravel outwash deposits (GD), which had greater RS stem mass. The total stem dry mass (ortet + associated RS) was comparable across the two different site types for both the 1-year-old coppiced plants and the 4-year-old uncoppiced plants, showing rapid recovery of biomass growth and yield in the year following coppicing. Significant clonal differences, as well as site type $\times$ clone interactions, were found for ortet stem dry mass, especially on SO sites, indicating that clonal selection might be useful to increase biomass production on different site types. When expressed as a fraction of total stem dry mass produced on $2 \mathrm{~m} \times 2 \mathrm{~m}$ biomass plots, the RS component represented a significant $57 \%$ of total stem dry mass per plot (ortet + associated RS) on GD sites and only $18 \%$ on SO sites. The use of colony-forming willows such as INT minimizes the need for periodic replanting, providing a cost advantage over conventional short-rotation, coppice-based woody biomass plantations using species that do not have the ability to produce new stems via root sprouting. This root-sprouting trait enables INT to rapidly colonize and spread on difficult-to-manage sites, making it suitable for use in land reclamation.
\end{abstract}

Key words: biomass partitioning, coppice biomass production, clonal variation, root sprout stem colony formation, Salix interior, site effects.

Résumé : Salix interior Rowlee (INT) est un saule nord-américain très répandu appartenant au petit groupe taxonomique Salix section Longifoliae, qui est remarquable par sa capacité à former des colonies d'origine végétative composées de nombreuses tiges provenant de drageons issus d'un réseau racinaire horizontal peu profond. La présente étude quantifie la production de biomasse par des plants recépés âgés d'un an et des plants d'origine âgés de quatre ans qui se sont établis à partir de boutures dormantes sans racines, et par des drageons associés à chaque ortet (plante mère d'origine) à l'aide de huit clones de INT établis sur deux types distincts de stations. La masse sèche des tiges d'ortet recépées ou non était significativement plus grande sur un sol recouvert d'un schiste argileux à texture grossière (SA), peut-être en raison de sa fertilité significativement plus élevée, que sur des dépôts adjacents composés de gravier d'épandage (DG) qui soutenaient une plus grande masse de drageons. La masse sèche totale des tiges (ortet et drageons associés) était semblable chez les plants recépés d'un an et les plants non recépés de quatre ans sur les deux types de stations, ce qui indique une récupération rapide de la croissance en biomasse et de la production au cours de l'année qui a suivi le recépage. Des différences significatives de masse sèche de tige d'ortet ont été observées entre les clones et entre les niveaux d'interaction entre le type de stations et les clones, en particulier sur les stations SA, ce qui indique que la sélection clonale pourrait être utile pour augmenter la production de biomasse sur différents types de stations. Lorsqu'elle était exprimée en proportion de la masse sèche totale des tiges produites sur des parcelles de $2 \mathrm{~m} \times 2 \mathrm{~m}$, la composante des drageons représentait $57 \%$ de la masse sèche totale des tiges par parcelle (ortet et drageons associés) sur les stations DG et seulement 18 \% sur les stations SA. L'utilisation de saules formant des colonies tel que le INT minimise le besoin de replantation périodique, ce qui constitue un avantage en matière de coût par rapport aux plantations conventionnelles de biomasse ligneuse à courte rotation qui utilisent des espèces qui n'ont pas la capacité de produire de nouvelles tiges à partir de drageons. Cette caractéristique de drageonnement permet à INT de s'établir et de se propager rapidement sur les stations difficiles à aménager, ce qui rend ce saule approprié pour une utilisation visant la remise en état des terres. [Traduit par la Rédaction]

Mots-clés : répartition de la biomasse, production de biomasse en taillis, variation clonale, formation de colonies de drageons, Salix interior, effets de la station.

Received 19 January 2021. Accepted 15 July 2021.

A. Mosseler and J.E. Major. Canadian Forest Service - Atlantic Forestry Centre, Natural Resources Canada, Fredericton, NB E3B 5P7, Canada.

Corresponding author: Alex Mosseler (email: alex.mosseler@canada.ca).

(c) 2021 The Crown. This work is licensed under a Creative Commons Attribution 4.0 International License (CC BY 4.0), which permits unrestricted use, distribution, and reproduction in any medium, provided the original author(s) and source are credited. 


\section{Introduction}

The genus Salix (willows) is a large taxonomic group consisting of approximately 350 species worldwide (Argus 2010). Canada has 76 native willow species (Argus 2010), some of which have generated interest in recent years for their rapid early growth and high biomass yields and for the potential they offer as a feedstock for bioenergy and for supporting the bioeconomy (Heller et al. 2003; Labrecque and Teodorescu 2005; Mirck and Schroeder 2013). Willows are able to invade highly disturbed areas (Barnes 1985; Ottenbreit and Staniforth 1992), making them useful for land reclamation on sites characterized by low fertility and potentially toxic effects, such as former mine sites (Hossner and Hons 1992; Wong 2003; Dowarah et al. 2009; Pedrol et al. 2010; Acton et al. 2011; Mosseler and Major 2015, 2017).

Salix interior Rowlee (INT) is a wide-ranging North American willow (Argus 2007) belonging to a small taxonomic group, Salix section Longifoliae (Dorn 1976, 1998; Argus 2007), which includes six or seven species. This group of Salix (Salicaceae) stands out for its ability to form colonies of multi-stemmed, vegetatively reproduced plants from root sprouts (RS) arising from a shallow horizontal root network (Del Tredici 2001; Grady et al. 2011). Primarily a colonizer of highly disturbed riparian habitats, INT is often associated with large river systems (Hosner and Minckler 1963; Noble 1979; Barnes 1985; Krasny et al. 1988a, 1988b; Ottenbreit and Staniforth 1992; Dixon 2003; Douhovnikoff et al. 2005; Zasada et al. 2008). Hinds (2000) describes INT (identified as Salix exigua Nutt.) as native to New Brunswick (NB) (see also Argus 2007); however, this species is now uncommon within the large watershed associated with the Saint John River Valley due to dam construction for hydroelectric power generation.

Twenty clones of INT were collected in eastern Ontario and were introduced into NB to assess their potential for biomass production and for their adaptability to the highly disturbed areas of a former coal mine near Minto, in central NB. This mine site required rapid revegetation and reclamation, particularly along streams draining the mine site, to prevent erosion and stream sedimentation due to surface water flows following heavy rains. Our main interest in INT was to assess its potential for land reclamation and for ecological restoration of extensive portions of highly disturbed sites associated with mining activities across Canada (Mosseler et al. 2020). This species' rapid growth, high biomass yields, ease of vegetative propagation from unrooted stem cuttings, and ability to rapidly colonize highly disturbed sites may also make INT a good choice for establishing bioenergy plantations (Mosseler et al. 2014a; Mosseler and Major 2015). Such plantations could be harvested much like a typical hay field, using traditional harvesting equipment with modified cutting heads adapted for small-diameter woody stems.

Stem colonies of INT can produce hundreds of stems arising from a single plant (clone). In areas such as the arid southwestern USA this species can produce a deep root system capable of penetrating soil substrates in search of the water table (Smith et al. 1998; Snyder and Williams 2000; Stella and Battles 2010). Once established, these deep roots can sustain INT during periods of seasonal drought. Willows could be used for rapid revegetation of highly disturbed sites, such as mine sites, allowing such sites to revert to native forest cover through the process of natural succession (Walker et al. 1986; Van Cleve et al. 1996; Zipper et al. 2011). Experience with land reclamation efforts on the Salmon Harbour coal mine site (NB) has shown that artificially established colonies of INT can rapidly expand and thrive on relatively dry infertile sites (Mosseler and Major 2015). Due to their shade intolerance, INT, and most other willows, are naturally succeeded by more shade-tolerant tree species that eventually replace INT colonies (McLeod et al. 2001).

This study follows up on an earlier investigation that characterized survival and early growth performance of INT clones established from unrooted dormant stem cuttings on a former coal mine site (Mosseler and Major 2015). In the present study, we distinguished between biomass production of the ortet and associated RS to gain insight into how growth was partitioned between the ortet and its associated RS, and we examined the effects of clone, coppicing, and site quality differences. We quantified the biomass yields of eight different INT clones established on lowfertility sites and the rate of recovery of biomass yields following coppicing, by comparing growth in 1-year-old coppiced plants with the original 4-year-old uncoppiced plants. Our objectives were to $(i)$ compare biomass yield of eight INT clones grown on two site types, (ii) compare RS biomass yield of coppiced and uncoppiced plants, and (iii) identify superior performing clones for both land reclamation and commercial biomass production on highly disturbed, low-fertility sites.

\section{Materials and methods}

The field test site was located in a narrow, shallow valley that had been landscaped and graded by heavy equipment to minimize soil erosion at the former Salmon Harbour coal mine operated by NB Power (public utility), near Minto, NB, Canada $\left(46^{\circ} 07^{\prime} \mathrm{N}, 66^{\circ} 05^{\prime} \mathrm{W}\right)$. Eight INT clones (Table 1 ) were established in April 2012, using 25 dormant stem cuttings, $20 \mathrm{~cm}$ in length, of each clone, collected during the winter months from clones selected through prior field testing (described in Mosseler and Major 2015). The 25 stem cuttings of each clone were established $2 \mathrm{~m}$ apart in linear clonal plots within rows extending for $50 \mathrm{~m}$ across (perpendicular to) the valley bottom. Each linear clonal row plot was spaced $2 \mathrm{~m}$ apart for a $2 \mathrm{~m} \times 2 \mathrm{~m}$ spacing between plants. Thus, the eight INT clones were represented by a single 25-stem (ramet) row plot within each of 10 physically separated sites (blocks). The two site types consisting of broken shale rock overburden (SO) and gravel outwash deposits (GD) were each represented by five physically separated sites (blocks).

Six soil samples were taken at a depth of approximately $15 \mathrm{~cm}$ from each of the two site types (see Mosseler and Major 2015). Standard soil analyses performed on these two different site types showed that nutrient properties were generally similar (Table 2); however, there were differences in soil texture and in depth of loose gravel associated with the GD sites, and significantly higher carbon (C), nitrogen $(\mathrm{N})$, and phosphorus $(\mathrm{P})$ concentrations on the SO sites.

After three full growing seasons, in October 2014 one of the largest plants (ramets) per clone from each linear 25-ramet $(50 \mathrm{~m}$ long) clonal plot was harvested to measure the aboveground biomass and to allow for coppice regrowth during the 2015 growing season. We purposely selected the largest plants from each clonal row plot for measurements because we were not interested in assessing the average biomass yield due to the extreme variability in growth across the $50 \mathrm{~m}$ line that transected the narrow valley bottomland along which the 25 ramets per clone had been established at a $2 \mathrm{~m}$ spacing. In most cases, the largest plants were located near the valley bottom due to better moisture conditions. Therefore, the coppiced and uncoppiced ortets were usually close or adjacent to each other (e.g., within 2-6 m apart). In November 2015, after one full growing season, the 1-year-old coppice regrowth was harvested and stem dry mass was determined following drying at $65{ }^{\circ} \mathrm{C}$ for $48 \mathrm{~h}$. Also, one of the largest 4-yearold uncoppiced ramets within each 25-ramet clonal plot was harvested and stem dry mass was determined. The number of coppice stems was counted on the 1-year-old coppiced plants and the length of the longest three stems of each coppice was measured to the nearest $1.0 \mathrm{~cm}$ using a flexible aluminum tape measure (see Mosseler et al. 2014b). The basal stem diameter of the three longest coppice stems was measured to the nearest $1.0 \mathrm{~mm}$ using an electronic caliper.

Using the coppiced and uncoppiced ortets (mother plants established as dormant, unrooted stem cuttings in 2012) as plot centres, all the RS that grew within a $2 \mathrm{~m} \times 2 \mathrm{~m}$ plot surrounding each ortet 
Table 1. Origins and morphological characteristics of Salix interior clones established in a common garden study at the Salmon Harbour mine site near Minto, NB, Canada.

\begin{tabular}{llll}
\hline Origin & Latitude; longitude & Clone $^{*}$ & Crown form description \\
\hline Ottawa, ON & $45^{\circ} 42^{\prime} \mathrm{N} ; 75^{\circ} 69^{\prime} \mathrm{W}$ & LAF-2, f & Bushy, upright stems; medium density branching \\
& & LAF-5, f & Few, tall, upright stems; sparsely branched \\
Roebuck, ON & $44^{\circ} 80^{\prime} \mathrm{N} ; 75^{\circ} 61^{\prime} \mathrm{W}$ & LIM-3, $\mathrm{m}$ & Compact, rotund bush; medium density branching \\
& & LIM-6, f & Few, upright stems; medium density branching \\
Long Sault, ON & $45^{\circ} 03^{\prime} \mathrm{N} ; 74^{\circ} 89^{\prime} \mathrm{W}$ & LON-2, $\mathrm{m}$ & Rotund bush; medium density branching \\
& & LON-3, m & Few, upright stems; sparse to medium density branching \\
& & LON-4, f & Few, upright stems; sparse to medium density branching \\
Pembroke, ON & $45^{\circ} 50^{\prime} \mathrm{N} ; 77^{\circ} 07^{\prime} \mathrm{W}$ & PEM-4, f & Many short upright stems; rotund bush; densely branched \\
\hline
\end{tabular}

were harvested, and the number of RS was counted. The total dry mass of all the RS associated with each biomass plot was determined. Although clonal differences in leaf form, stem colouration, and stage of leaf senescence generally allowed us to associate the RS with a particular clonal plot, we could not be completely certain that each RS tallied within this $2 \mathrm{~m} \times 2 \mathrm{~m}$ plot originated from the INT plant (ortet) or clone at the centre of each biomass plot.

A three-way ANOVA was used to assess the statistical significance of differences among site type, clone, and plant type (coppiced vs. uncoppiced) for biomass traits for each of the eight INT clones, using the following linear model:

$$
Y_{i j k l m}=\mu+B_{i(j)}+S_{j}+C_{k}+P_{l}+\mathrm{SC}_{j k}+\mathrm{SP}_{j l}+\mathrm{CP}_{k l}+e_{i j k l m}
$$

where $\mu$ is the overall mean, $Y_{i j k l m}$ is the dependent ramet trait from the $i$ th block nested within the $j$ th site type of the $k$ th clone of the $l$ th plant type and the $m$ th ramet of the $k$ th clone, $B_{i(j)}$ is the $i$ th block nested within the jth site type, $S_{j}$ is the effect of the $j$ th site type (shale overburden vs. gravel outwash deposit), $C_{k}$ is the effect of $k$ th clone ( $k=1$ to 8 ), $P_{l}$ is the effect of the lth plant type ( $l=1$-year-old coppiced vs. 4-year-old uncoppiced), $\mathrm{SC}_{j k}$ represents the site $\times$ clone interaction, $\mathrm{SP}_{j l}$ represents the site $\times$ plant type interaction, $\mathrm{CP}_{k l}$ represents the clone $\times$ plant type interaction, and $e_{i j k l m}$ is the random error term. The 3-way interaction between site type $\times$ clone $\times$ plant type was not included in our linear model because it was always non-significant (i.e., for ortet stem dry mass, $P=0.969)$ and thus we chose to collapse the variability attributable to this three-way interaction and the corresponding degrees of freedom into the error term of the ANOVA. Site types, clones, and plant types were all considered fixed effects for ANOVA. The general linear model in SYSTAT (Chicago, Illinois) was used for this analysis. All statistical tests used a significance level of $P=0.05$. A Tukey's mean separation test was used for multiple comparisons.

A two-way ANOVA was used to assess growth trait differences (coppice stem number, stem height and basal stem diameter of coppice stems) for the 1-year-old coppiced plants among site types and clones, for the eight INT clones, using the following linear model:

$$
Y_{i j k l}=\mu+B_{i(j)}+S_{j}+C_{k}+S_{j k}+e_{i j k l}
$$

where $\mu$ is the overall mean, $Y_{i j k l}$ is the dependent ramet trait from the $i$ th block nested within the $j$ th site type of the $k$ th clone of the $l$ th ramet of the $k$ th clone of 1-year-old coppiced plants, $B_{i(j)}$ is the $i$ th block nested within the $j$ th site type, $S_{j}$ is the effect of the $j$ th site type (shale overburden vs. gravel outwash deposit), $C_{k}$ is the effect of $k$ th clone ( $k=1$ to 8 ), $S_{j k}$ represents the site $\times$ clone interaction, and $e_{i j k l}$ is the random error term. Site types and clones were considered fixed effects for ANOVA. The general linear model in SYSTAT (Chicago, Illinois) was used for this analysis. All statistical tests used a significance level of $P=0.05$. A Tukey's mean separation test was used for multiple comparisons.
Covariate analysis was used to evaluate allometric biomass trait interrelationships and site type effects on these relationships. In these analyses, three sources of variation were studied: (1) covariate (i.e., coppice stem number), (2) independent effect (i.e., site type), and (3) independent effect $\times$ covariate. The analyses were conducted using the following model:

$$
\text { (3) } \quad Y_{i j}=B_{0}+B_{0 i}+B_{1} X_{i j}+B_{1 i} X_{i j}+e_{i j}
$$

where $Y_{i j}$ is the dependent trait of the $i$ th species of the $j$ th genus, $B_{0}$ and $B_{1}$ are average regression coefficients, $B_{0 i}$ and $B_{1 i}$ are the genus specific coefficients, $X_{i j}$ is the independent variable, and $e_{i j}$ is the error term. The results were considered statistically significant at $P=0.05$. The general linear model in SYSTAT was used for this analysis. The variance component analysis was conducted using the sum of squares as described by Hicks (1982).

\section{Results}

Soil analyses showed significant differences between the SO and GD sites in terms of the proportions of sand, silt, and clay (Table 2). Although the soil at the two types of sites is derived from the same shale parent material, $\mathrm{N}$ and $\mathrm{P}$ concentrations were $46 \%$ and $215 \%$ greater for SO sites relative to GD sites, respectively. The $C$ content was almost twice as high on the SO sites.

Biomass production has been presented as plant dry mass (g). Estimates of dry mass per area can be obtained by multiplying the figures for plant dry mass by 2500 to get kilograms per hectare. Site type, clone, and plant type all showed significant effects on ortet stem dry mass and there was a significant site type $\times$ clone interaction (Table 3). On average, SO sites had 2.5 times greater aboveground ortet stem dry mass than GD sites (Fig. 1a). The plant type effect was consistent across both site types, with 1-year-old coppiced having $59 \%$ of the stem dry mass measured for 4-year-old uncoppiced ortets. The clone effect had the largest independent variance (15.9\%; Table 3 ) for ortet stem dry mass and displayed large variations among the INT clones (Fig. 2a). The site type $\times$ clone interaction was the result of both a magnitude effect and rank changes. Clearly, LIM-3 and LAF-2 performed much better on the SO sites. The SO sites had a ranking ortet stem dry mass that was greater than or equal to that of GD sites for seven of the eight clones. The only rank change observed was for clone PEM-4, which performed better on GD sites than on SO sites. The associated RS stem dry mass only showed a significant effect on stem dry mass for site type, accounting for $18.3 \%$ of the total variation (Table 3). The GD sites had 4.7 times more RS stem dry mass than SO sites (Fig. 1b). Although nearly statistically significant, plant type showed that 1-year-old coppiced had almost $50 \%$ more RS stem dry mass than 4-year-old uncoppiced ortets $(P=0.080)$. The higher values for RS stem dry mass on GD sites is a finding that was consistent across clones (Fig. 2b). When ortet and RS stem dry mass values were combined, it was found that total stem dry mass was no longer significant for either site type or plant type (Table 3; Fig. 1c). Both clone and clone $\times$ site type 
Table 2. Soil properties for the two site types, gravel outwash deposits and shale rock overburden, of the Salmon Harbour coal mine near Minto, NB, Canada.

\begin{tabular}{|c|c|c|c|c|c|c|c|c|c|c|c|c|c|c|}
\hline$\underline{\text { Site type }}$ & $\begin{array}{l}\text { Organic } \\
\text { matter (\%) }\end{array}$ & Carbon (\%) & Nitrogen (\%) & $\begin{array}{l}\begin{array}{l}\text { Potassium } \\
\left(\text { meq. } 100 \mathrm{~g}^{-1} \text { ) }\right.\end{array} \\
\end{array}$ & $\begin{array}{l}\begin{array}{l}\text { Calcium } \\
\text { (meq. } 100 \mathrm{~g}^{-1} \text { ) }\end{array} \\
\end{array}$ & $\begin{array}{l}\text { Magnesium } \\
\left(\text { meq. } 100 \mathrm{~g}^{-1} \text { ) }\right.\end{array}$ & $\begin{array}{l}\text { Phosphorus } \\
\text { (ppm) }\end{array}$ & Sulfur (\%) & $\begin{array}{l}\text { C:N ratio } \\
(\%)\end{array}$ & $\mathrm{pH}$ & $\operatorname{Rock}(\%)^{*}$ & Sand (\%) & Silt (\%) & Clay (\%) \\
\hline Gravel outwash deposits & $5.28 \pm 1.12 \mathrm{a}$ & $0.15 \pm 0.03 b$ & $0.048 \pm 0.005 b$ & $0.158 \pm 0.019 \mathrm{a}$ & $7.21 \pm 0.52 \mathrm{a}$ & $0.96 \pm 0.09 \mathrm{a}$ & $2.00 \pm 0.70 \mathrm{~b}$ & $0.018 \pm 0.006 \mathrm{a}$ & $3.1 \pm 0.5 \mathrm{a}$ & $6.4 \pm 0.3 a$ & $32.2 \pm 7.7 \mathrm{a}$ & $72.2 \pm 4.9 \mathrm{a}$ & $23.1 \pm 4.4 \mathrm{~b}$ & $4.6 \pm 0.7 \mathrm{~b}$ \\
\hline Shale rock overburden & $3.54 \pm 1.12 \mathrm{a}$ & $0.27 \pm 0.03 \mathrm{a}$ & $0.070 \pm 0.005 \mathrm{a}$ & $0.198 \pm 0.019 \mathrm{a}$ & $8.53 \pm 0.52 \mathrm{a}$ & $1.10 \pm 0.09 \mathrm{a}$ & $4.33 \pm 0.70 \mathrm{a}$ & $0.021 \pm 0.006 \mathrm{a}$ & $4.0 \pm 0.5 \mathrm{a}$ & $5.9 \pm 0.3 a$ & $29.7 \pm 7.7 \mathrm{a}$ & $28.0 \pm 4.9 \mathrm{~b}$ & $57.5 \pm 4.4 \mathrm{a}$ & $14.4 \pm 0.7 \mathrm{a}$ \\
\hline
\end{tabular}

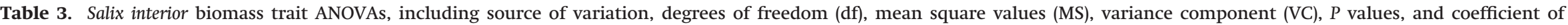
determination $\left(R^{2}\right)$.

\begin{tabular}{|c|c|c|c|c|c|c|c|c|c|c|c|c|c|c|c|c|}
\hline \multirow[b]{2}{*}{ Source of variation } & \multirow[b]{2}{*}{ df } & \multicolumn{3}{|c|}{ Ortet stem dry mass (g) } & \multicolumn{3}{|c|}{ Root sprout stem dry mass (g) } & \multicolumn{3}{|c|}{ Total stem dry mass (g) } & \multicolumn{3}{|c|}{ Root stem number } & \multicolumn{3}{|c|}{$\begin{array}{l}\text { Root sprout dry mass as a } \\
\% \text { of total stem dry mass }\end{array}$} \\
\hline & & $\mathrm{MS}\left(\times 10^{3}\right)$ & VC (\%) & $P$ value & $\operatorname{MS}\left(\times 10^{3}\right)$ & VC (\%) & $P$ value & $\operatorname{MS}\left(\times 10^{3}\right)$ & $\mathrm{VC}(\%)$ & $P$ value & MS & $\mathrm{VC}(\%)$ & $P$ value & VMS & VC (\%) & $P$ value \\
\hline Block (site type) & 8 & 5.9 & 14.6 & 0.001 & 2.0 & 9.4 & 0.071 & 26.1 & 15.8 & 0.001 & 179 & 8.8 & 0.035 & 563 & 3.2 & 0.574 \\
\hline Site type & 1 & 68.2 & 5.4 & 0.001 & 30.9 & 18.3 & $<0.001$ & 7.2 & 0.5 & 0.308 & 4551 & 27.8 & $<0.001$ & 40547 & 29.2 & $<0.001$ \\
\hline Clone & 7 & 28.5 & 15.9 & $<0.001$ & 0.2 & 0.9 & 0.983 & 28.0 & 14.8 & 0.001 & 82 & 3.5 & 0.437 & 1443 & 7.3 & 0.046 \\
\hline Plant type & 1 & 28.1 & 2.2 & 0.031 & 3.3 & 2.0 & 0.080 & 11.0 & 0.8 & 0.209 & 53 & 0.3 & 0.425 & 13127 & 9.4 & $<0.001$ \\
\hline Site type $\times$ clone & 7 & 24.1 & 13.5 & 0.001 & 1.3 & 5.3 & 0.304 & 29.0 & 15.3 & $<0.001$ & 114 & 4.9 & 0.220 & 493 & 2.5 & 0.646 \\
\hline Site type $\times$ plant type & 1 & $<0.1$ & $<0.1$ & 0.989 & $<0.1$ & $<0.1$ & 0.781 & $<0.1$ & $<0.1$ & 0.988 & 95 & 0.6 & 0.285 & 29 & $<0.1$ & 0.835 \\
\hline Clone $\times$ plant type & 7 & 3.8 & 2.1 & 0.721 & 1.1 & 9.4 & 0.391 & 3.0 & 1.6 & 0.877 & 100 & 4.3 & 0.300 & 376 & 1.9 & 0.788 \\
\hline Error & 99 & 22.8 & 46.4 & & 1.0 & 59.5 & & 6.9 & 51.2 & & 179 & 49.8 & & 674 & 46.5 & \\
\hline$R^{2}$ & & & & 0.506 & & & 0.395 & & & 0.457 & & & 0.492 & & & 0.538 \\
\hline
\end{tabular}

Note: $P$ values in bold indicate that the biomass trait was significantly affected by the source of variation at $P<0.05$. 
Fig. 1. (a) Stem dry mass of the ortet (mother plant), (b) stem dry mass from root sprouts associated with each ortet, and $(c)$ total aboveground stem mass of the ortet, plus stems from root sprouts associated with each ortet, based on the ANOVA results shown in Table 3 for both 1-year-old coppiced plants and 4-year-old uncoppiced plants.
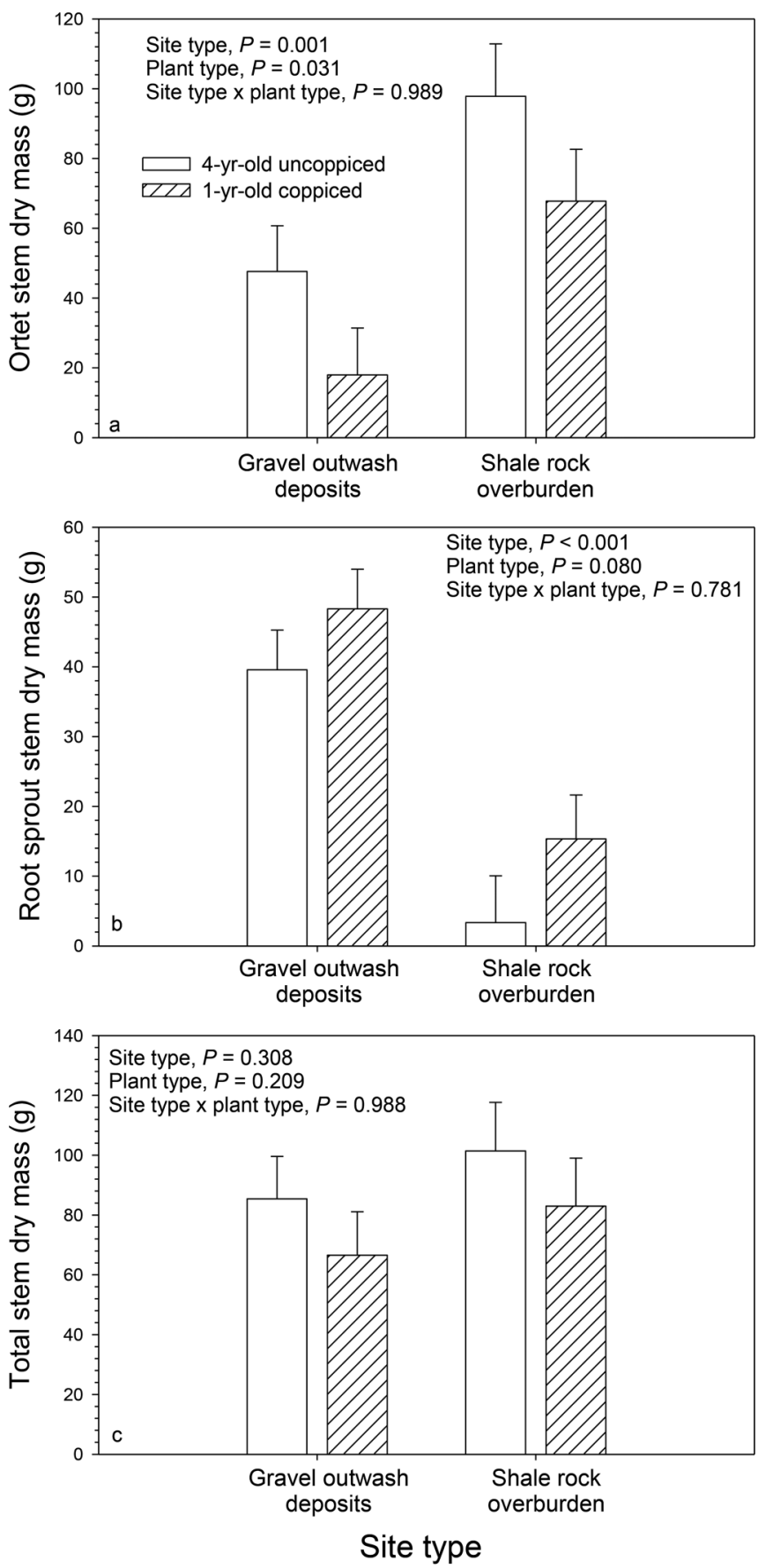

interaction were significant for total stem dry mass (Fig. 2c). The clone $\times$ site type interaction was the result of strong rank changes. Total stem dry mass was greater on SO sites compared with GD sites for only two clones, LIM-3 and LAF-2; the other six clones had total stem dry mass on GD sites that was equal to or greater than that on SO sites.

Root sprout stem dry mass expressed as a fraction (percent) of total aboveground stem dry mass (ortet + associated RS for each
Fig. 2. Response of eight Salix interior clones for (a) stem dry mass of the ortets (mother plants), (b) stem dry mass from root sprouts associated with each ortet, and (c) total aboveground stem mass of the ortet plus associated root sprouts, based on the ANOVA results shown in Table 3 for both 1-year-old coppiced and 4-year-old uncoppiced plants.
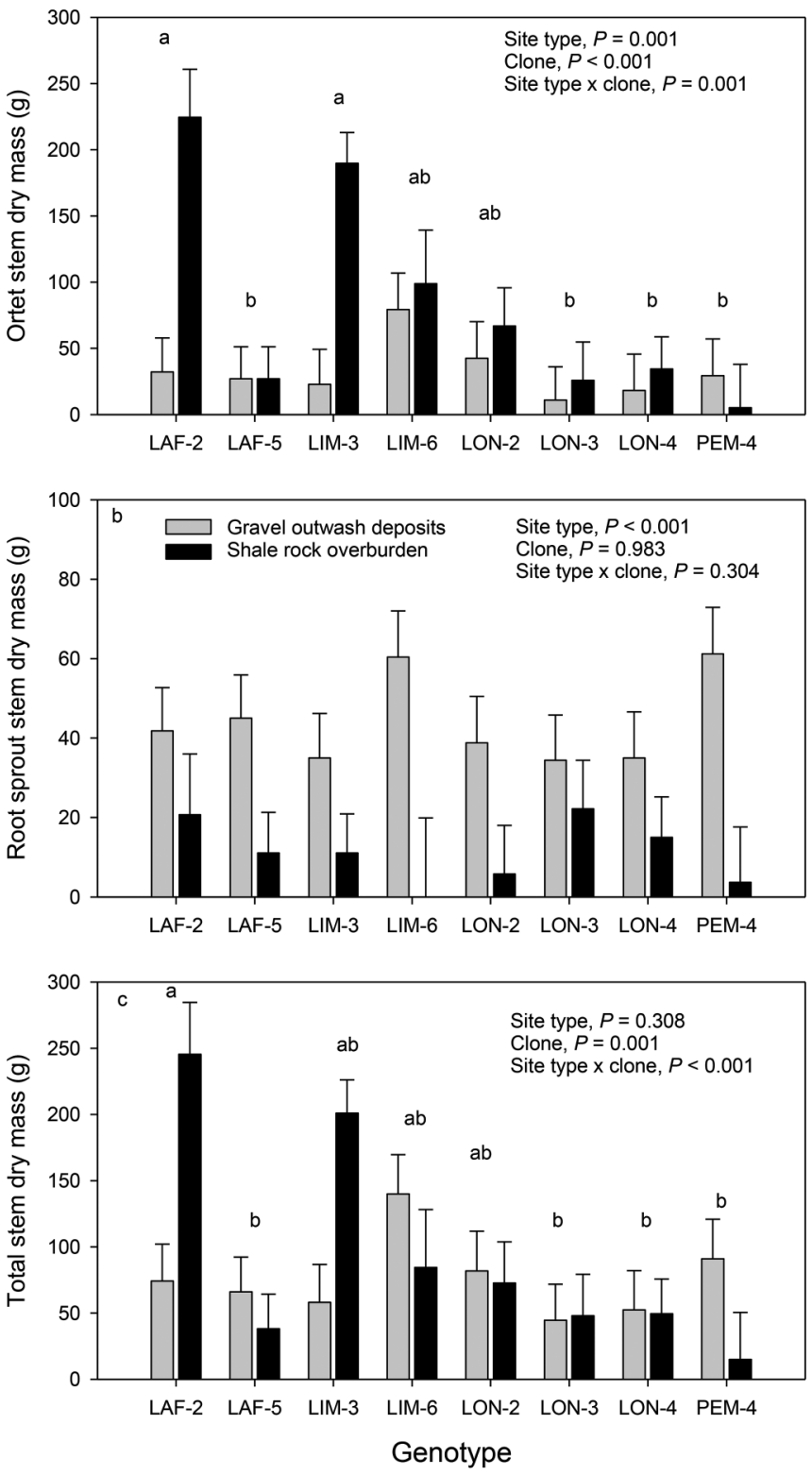

$2 \mathrm{~m} \times 2 \mathrm{~m}$ biomass plot) showed that site type, clone, and plant type had significant effects on biomass allocation (Table 3). Site type had a very large effect, accounting for $29.2 \%$ of total variation, whereas clone and plant type accounted for only $7.3 \%$ and $9.4 \%$ of total variation, respectively. Regardless of site type, the fraction of biomass attributed to RS of 1-year-old coppiced plants always significantly exceeded that of 4-year-old uncoppiced plants (Fig. 3a). For 1-year-old coppiced plants, RS stem dry mass accounted for $67 \%$ and $7 \%$ of the total plot biomass on GD and SO sites, respectively. Differences in percent RS stem dry mass expressed as a percentage of total aboveground stem dry mass within each biomass plot were significant among the eight INT clones $(P=0.046)$, and this biomass fraction was always larger on GD sites than on SO sites (Fig. 3b). 
Table 4. Biomass trait ANOVAs for 1-year-old coppiced plants of Salix interior, including source of variation, degrees of freedom (df), mean square values (MS), variance component (VC), $P$ values, and coefficient of determination $\left(R^{2}\right)$.

\begin{tabular}{|c|c|c|c|c|c|c|c|c|c|c|c|c|c|}
\hline $\begin{array}{l}\text { Source of } \\
\text { variation }\end{array}$ & $\mathrm{df}$ & \multicolumn{3}{|c|}{ Coppice stem number } & \multicolumn{3}{|c|}{ Coppice root sprout number } & \multicolumn{3}{|c|}{ Mean coppice height (m) } & \multicolumn{3}{|c|}{$\begin{array}{l}\text { Mean coppice stem basal } \\
\text { diameter }(\mathrm{mm})\end{array}$} \\
\hline Block (site type) & 8 & 66.3 & 22.8 & 0.023 & 151 & 15.2 & 0.102 & 0.124 & 17.2 & 0.136 & 3.93 & 16.2 & 0.102 \\
\hline Clone & 7 & 44.8 & 13.6 & 0.125 & 106 & 9.4 & 0.285 & 0.043 & 5.3 & 0.451 & 1.63 & 3.2 & 0.341 \\
\hline Site type $\times$ clone & 7 & 54.6 & 16.6 & 0.062 & 108 & 9.6 & 0.274 & 0.074 & 9.0 & 0.136 & 4.59 & 9.1 & 0.102 \\
\hline Error & 42 & 25.7 & 48.3 & & 83 & 44.2 & & 0.074 & 54.4 & & 3.93 & 47.0 & \\
\hline
\end{tabular}

Note: $P$ values $<0.05$ are in bold print.

Fig. 3. (a) Percent root sprout stem dry mass of the ortets (mother plants), for both coppiced and uncoppiced plants, and (b) root sprout stem dry mass percentage of the total aboveground dry mass (ortet + associated root sprouts), based on the ANOVA results shown in Table 3.
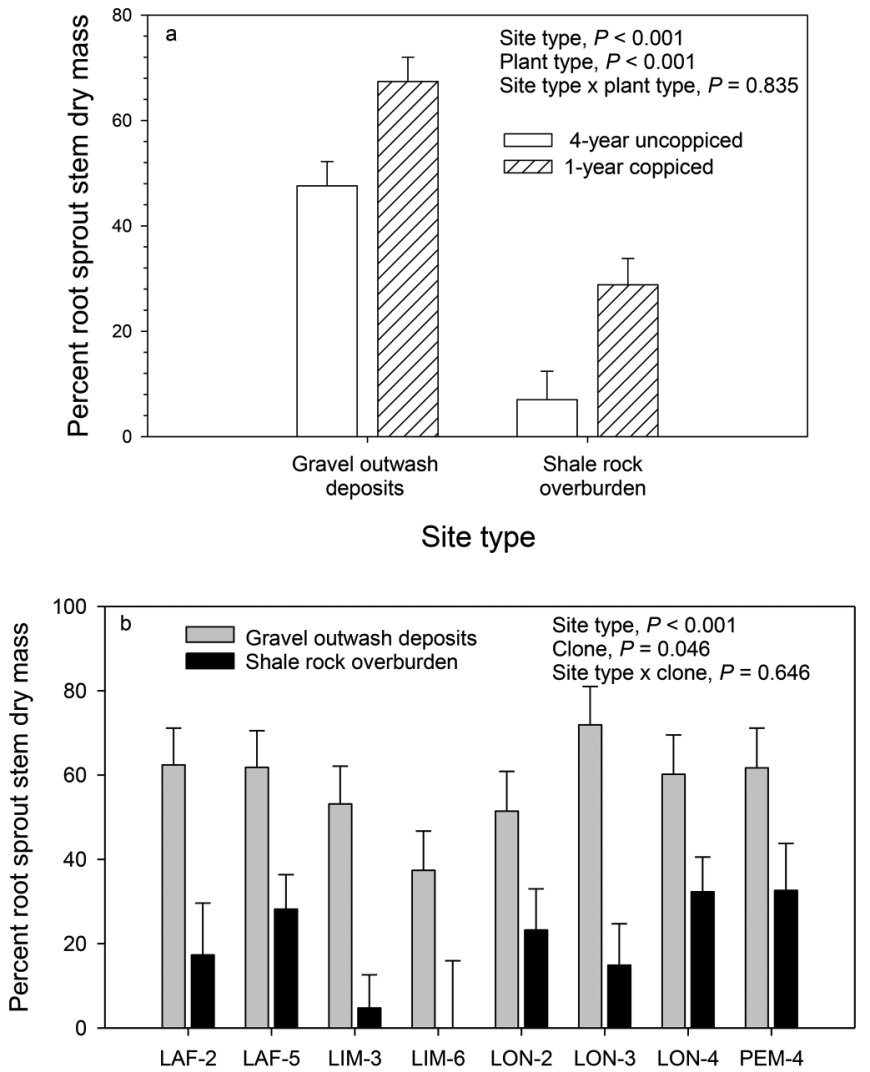

Genotype

Stem number of coppiced plants had no significant site type or clone effects (Table 4; Fig. 4a). Coppice stem number showed a nearly significant site type $\times$ clone interaction $(P=0.062)$ due to rank changes of site type depending on clone. There were significant differences in RS stem number between the different site types, with a significantly greater RS stem number on GD sites relative to SO sites, and this result was fairly consistent across clones (Table 4; Fig. 4b). For the means (top three stems) of both coppice stem height and stem basal diameter, there were significant differences between the two site types, with both stem height and diameter being significantly greater on SO sites than on GD sites (Table 4; Fig. 5).

Covariate analysis of coppice RS stem dry mass in relation to coppice ortet stem dry mass (covariate) across clones and testing for site type showed neither a site type $\times$ coppice ortet stem dry mass interaction $(P=0.097)$ nor a coppice ortet stem dry mass effect $(P=0.444)$. However, there was a significant site effect $(P=0.005)$, as shown by the two horizontal lines in Fig. $6 a$, which reflect differences in site type only. Covariate analysis of coppice RS number in relation to coppice stem number showed no site type $\times$ coppice stem number interaction $(P=0.362)$. However, the covariate analysis results for coppice stem number and site type were significant $(P=0.039, P<0.001)$ as shown by the two positive sloped lines in Fig. $6 b$, with the line for GD sites above that for SO sites. Covariate analysis of mean coppice stem height in relation to mean coppice basal stem diameter (covariate) and testing for site type showed neither a site type $\times$ coppice basal stem diameter interaction $(P=0.466)$ nor a site type effect $(P=0.650)$, resulting in a single positive slope line in Fig. $6 c\left(R^{2}=0.723\right)$.

Covariate analysis of coppice ortet stem dry mass in relation to coppice stem number across clones and testing for site type showed a significant site type $\times$ coppice stem number interaction $(P=0.001)$. The result was a greater slope for $S O$ sites than for GD sites (Fig. 7a). Covariate analysis of coppice RS stem dry mass in relation to coppice RS number showed neither a site type $\times$ coppice RS stem number interaction $(P=0.819)$ nor any site type effect $(P=0.405)$, resulting in a single positive slope $(P<0.001$, Fig. 7b).

\section{Discussion}

Woody stem proliferation via RS is not common among angiosperms and is quite rare among gymnosperms. In most rootsprouting tree species, this type of sprouting generally occurs in response to injury to the ortet (Bosela and Ewers 1997; Sakai et al. 1997; Del Tredici 2001; Rodrigues et al. 2004). Scientists and forest ecologists have investigated many different aspects of the ecology of RS (Kammesheidt 1999; Bond and Midgley 2003; Saha and Howe 2003; Vesk and Westoby 2004; Guerrero-Campo et al. 2006; Wiehle et al. 2009). However, few studies have examined the allometric relationships that influence biomass partitioning and allocation to RS versus the ortet, nor have many studies considered the implications for commercial biomass production or for the colonization of open areas, for land reclamation and revegetation purposes (Mosseler and Major 2015). Ecologically, root sprouting is an important trait in species that occupy disturbed habitats, because it allows plants to spread into adjacent, disturbed areas. Little attention has been devoted to population dynamics and biomass allocation to RS (Barnes 1985; Ottenbreit and Staniforth 1992), especially considering the importance of these characteristics from the standpoint of productivity and commercial woody biomass production. Salix interior is a species that frequently 
Fig. 4. Response of eight Salix interior clones from 1-year-old coppiced plants for (a) coppice stem number produced by the ortet (mother plants) and (b) stem number of the root sprouts associated with each ortet, based on the ANOVA results shown in Tables 3 and 4, respectively.
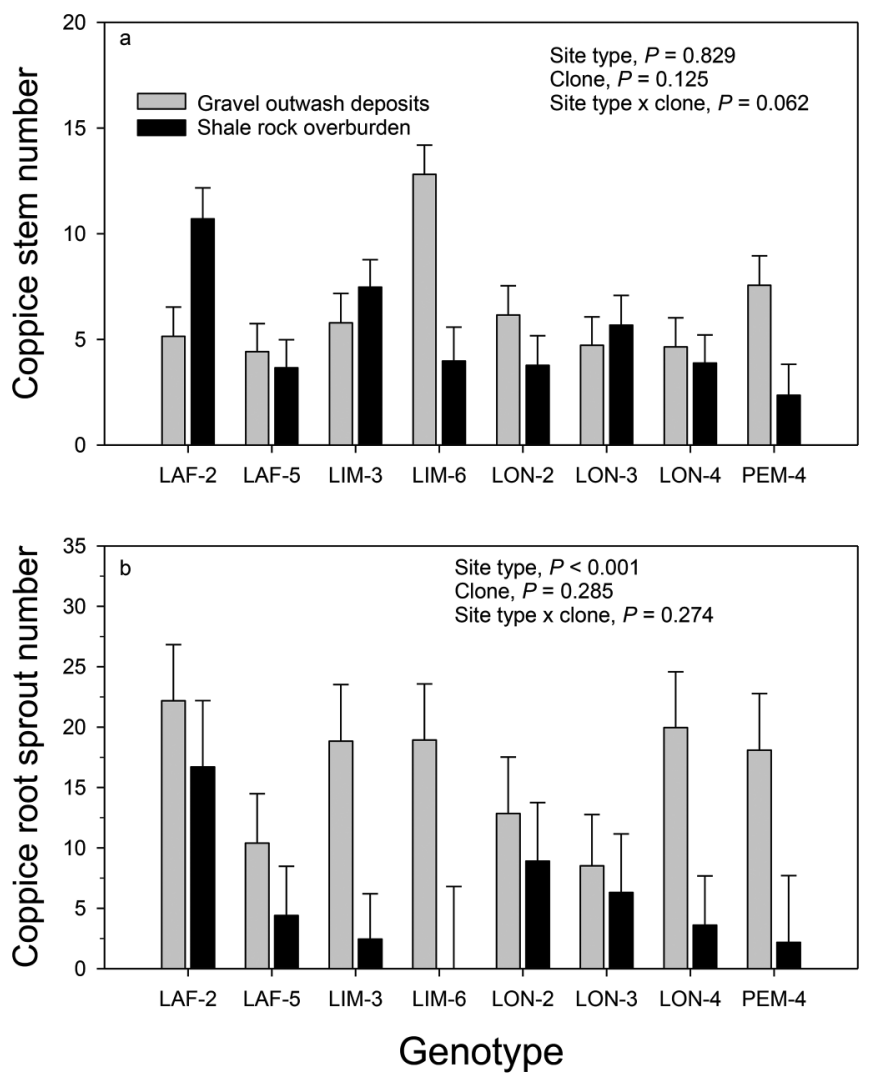

occupies disturbed riparian zones and produces abundant RS in the absence of injury to the plant.

The eight INT clones used in this study varied in plant morphology; hence, each clone had some unique features that were useful in differentiating clones within common-garden studies. Phenological differences in autumn leaf colouration and leaf persistence were particularly useful in separating RS belonging to different clones. Morphological features such as height, uprightness of coppice stems, or plant bushiness could also be used in clonal selection for biomass production traits, with the aim of identifying clones best suited to bioenergy plantation management. Features such as stem number and size, basal stem diameter, and stem uprightness can also influence harvesting equipment design for short-rotation biomass production systems (Savoie et al. 2009, 2013).

Differences in growth or biomass accumulation between 1-year-old coppiced ortets and 4-year-old uncoppiced ortets were not surprising, given the age differences between these different plant types. However, the rapid recovery of growth in coppicing plants is noteworthy, especially on SO sites, with coppiced plants regaining $69 \%$ of their pre-harvest stem dry mass within one full growing season following the harvesting of aboveground biomass (Fig. 1a) (see Mosseler et al. 2019 for similar results in bur oak). Despite the comparatively low $\mathrm{N}$ concentration that is characteristic of soils associated with recent surface mining operations (Hansen et al. 1988; Pedrol et al. 2010), willows tend to grow reasonably well on such infertile soils (Krasny et al. 1988a; Van Cleve et al. 1996; Mosseler et al. 2014a; Mosseler and Major 2015). Both poplars and willows are capable of fixing $\mathrm{N}$ via endophytes in their stems, a
Fig. 5. Response of eight Salix interior clones from 1-year-old coppiced plants for $(a)$ mean coppice stem height and $(b)$ mean basal stem diameter for coppice stems, based on the ANOVA results shown in Table 4.
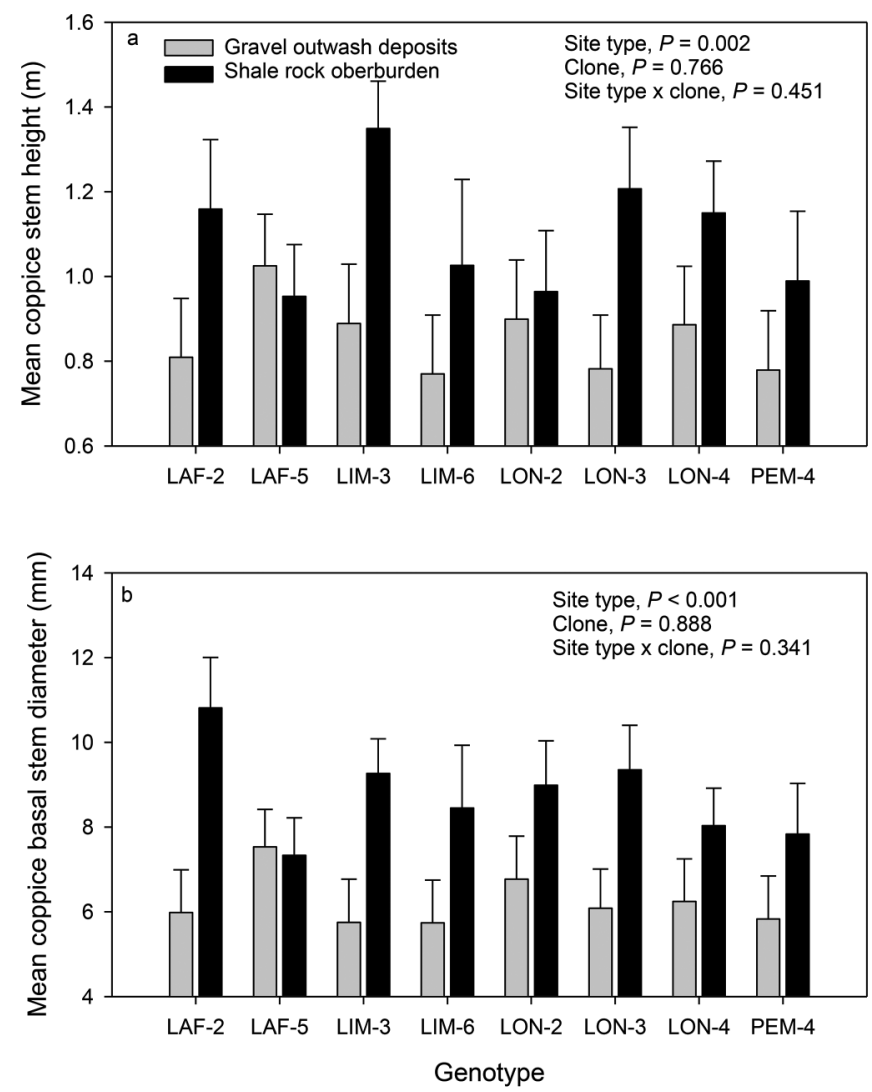

factor that could have a major positive effect on their ability to grow on infertile, impoverished sites (Doty et al. 2009; Knoth et al. 2014). Short-rotation willow and poplar (Populus) culture may also be useful for improving some aspects of soil fertility, in particular the soil C content (Hansen 1993; Jug et al. 1999; Dimitriou et al. 2012; Schrama et al. 2016). Schrama et al. (2016) found that much of the $\mathrm{N}$ taken up by willows in short-rotation cultures is returned to the soil through annual leaf fall litter and fine root turnover, and that willows showed comparatively high rates of soil $\mathrm{N}$ mineralization. Nitrogen is often a key limiting soil nutrient, and the significantly higher $C$, $\mathrm{N}$, and P levels on SO sites may explain the larger size of both coppiced and uncoppiced ortets on SO sites.

Understanding allometric relationships is important for characterizing and modelling biomass growth and yield traits, for assessing the economic viability of bioenergy plantations, and for assessing species' suitability for use in biomass production systems (Ceulemans et al.1996; Sixto et al. 2011; van Breugel et al. 2011; Mosseler et al. 2014b; Mosseler and Major 2015). If we consider biomass production in 1-year-old coppiced plants (Fig. 1), it is clear that total aboveground stem dry mass (ortet + associated RS) did not differ significantly across site types (Fig. 1c); however, biomass production was partitioned very differently on the two different site types due to soil differences. A significantly greater proportion of the total RS biomass produced (57\%) was measured on GD sites (Fig. 1b), whereas greater stem dry mass and the proportion of ortet biomass (82\%) was greater on SO sites (Fig. 1a). The latter effect was probably related to the greater fertility ( $\mathrm{N}$ and $\mathrm{P}$ ) of the SO sites. It appears that the looser gravel soil type characterizing the GD sites favoured lateral root egress to a point 
Fig. 6. Allometric relationships for eight Salix interior clones from 1-year-old coppiced plants for (a) stem dry mass of coppice root sprouts and coppice ortet stem dry mass, $(b)$ the coppice root sprout stem number and coppice ortet stem number, and $(c)$ mean coppice stem height and mean coppice basal stem diameter.
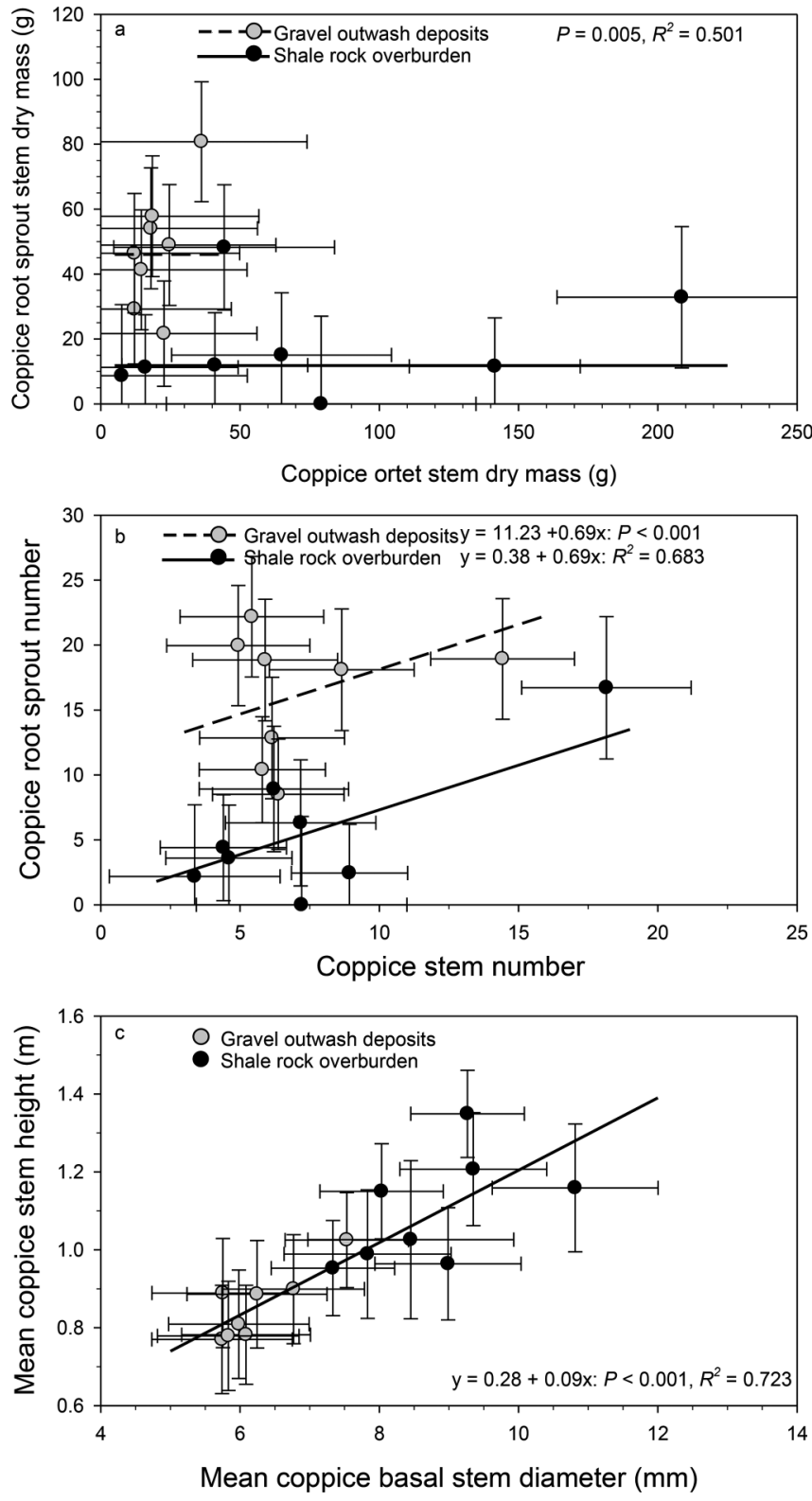

that promoted significantly more biomass production within stems arising from RS than in the associated ortets (Figs. 1, 2b, 3, and $4 b$ ).

Does RS stem dry mass have a negative effect on coppice ortet stem dry mass or are these competing carbohydrate sinks? The answer is no; regardless of the coppice ortet stem dry mass. Despite the wide variation in coppice ortet dry mass, there was no significant relationship with RS stem dry mass for either site type (Fig. 6a). However, a significant positive relationship was found between the coppice stem number and the plot RS stem number for both site types (Fig. 6b). These RS relationships may be particularly important for biomass production in root-sprouting species such as INT and aspens (e.g., Populus tremuloides Michx. and Populus grandidentata Michx.) because RS can make up a large
Fig. 7. Allometric relationships for eight Salix interior clones from 1-year-old coppiced plants for (a) coppice ortet stem dry mass and coppice stem number, and (b) coppice root sprout stem dry mass and the coppice root sprout stem number associated with each ortet.
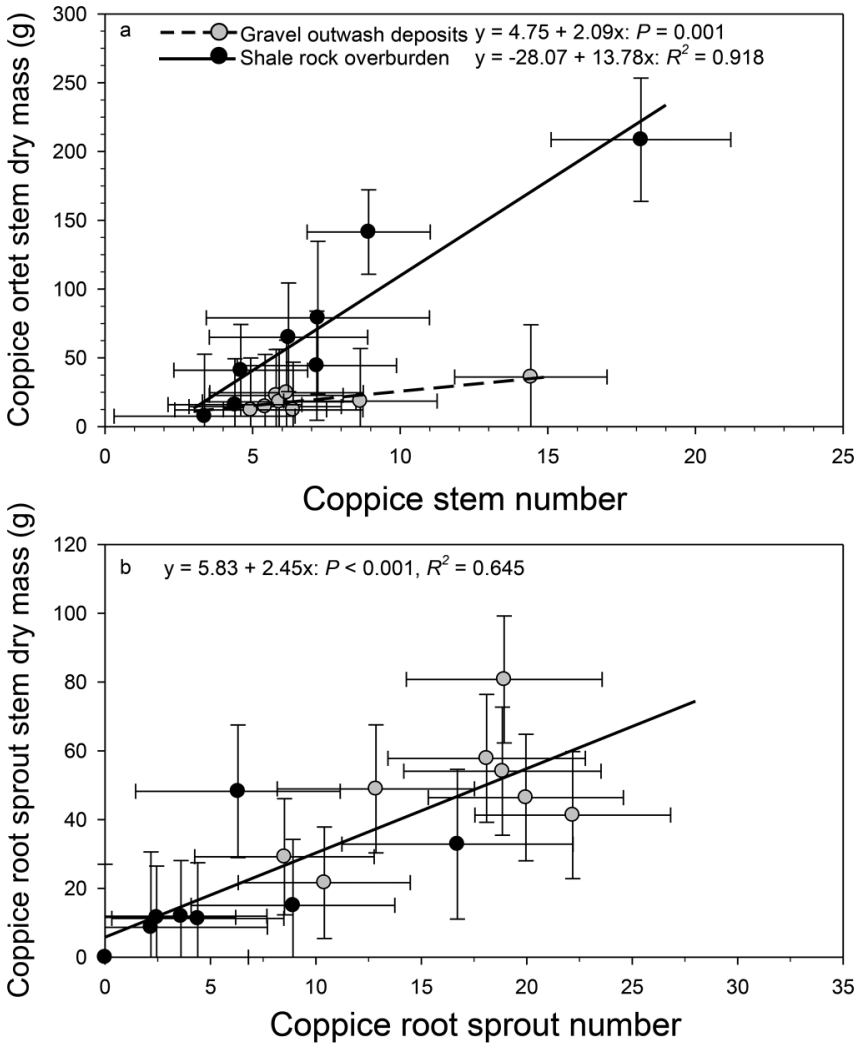

proportion of aboveground stem dry mass (Kemperman and Barnes 1976; Mitton and Grant 1996). They also have implications for biomass yields from bioenergy production plantations. The distribution of aboveground stem biomass production and growth in INT is much more complex than in non-root-sprouting willows, and this root-sprouting trait was strongly influenced by site quality.

Another allometric relationship worthy to note is the relationship between mean coppice stem height and mean coppice stem basal diameter, which was the same for the two sites, but biomass production on GD sites was segregated at the lower end, and SO at the higher end, of this relationship (Fig. $6 c$ ). This stands in contrast to the findings of a previous study investigating biomass allometry in Salix eriocephala and Salix discolor on three different sites, where the relationship between mean coppice height and basal stem diameter was found to be affected by site type (Mosseler et al. 2014b). In that study, on better quality or more fertile sites, coppice height was found to increase for a given basal stem diameter. In the present study, the relationship between stem dry mass and stem number differed between coppice ortet and RS. The relationship between coppice ortet stem dry mass and coppice stem number was highly positive on SO sites. On GD sites, this relationship produced a much flatter, slightly positive linear response. The positive relationship between coppice dry mass and coppice stem number indicates that selection for coppice stem number may be an important and easily identified coppice trait in INT for assessing biomass production (Mosseler et al. 2016). These allometric relationships indicate that soil and (or) site effects have a strong influence on biomass production. The relationship between coppice RS stem dry 
mass and coppice RS stem number was defined by a single line for both site types; however, the data for GD sites were again segregated at the lower end, and SO sites at the upper end, of this relationship. This points to the possibility of carrying out clonal selection based on either coppice stem or coppice RS numbers as simple selection criteria for improvement of biomass production.

Does coppicing stimulate RS stem production or growth? Two lines of evidence can be used to examine this question. Yes, coppiced RS stem dry mass was greater for both site types when compared with uncoppiced RS stem dry mass, but the significance level was low (plant type, $P=0.080$, Table 3 ). When we examined coppiced RS stem dry mass as a percentage of total stem dry mass, coppiced plants had greater RS stem mass proportions than uncoppiced plants (plant type, $P<0.001$, Fig. $3 a$ ), suggesting that coppicing stimulates RS stem dry mass production while still stimulating ortet stem mass.

The significantly greater biomass yields obtained for some INT clones (e.g., LAF-2 and LIM-3), along with the significant clone $\times$ site type interaction, indicate that clonal selection may optimize biomass production of INT on specific site types (Fig. 2a). From Fig. $2 b$, it can be seen that GD sites created a significantly more favourable environment for RS development. This effect can be explained by the looser nature of the predominantly gravel soil present on the five GD sites compared with SO sites, which favoured root egress into the less compacted soil substrate (Caplan et al. 2013). This is important given that clonal variation in RS stem biomass on the GD and SO sites, for both 1-year-old coppiced plants and 4-year-old uncoppiced plants, explained a large proportion of the variation in overall aboveground biomass yields, which ranged from $37 \%$ to $72 \%$ and from $0 \%$ to $32 \%$ of total aboveground stem dry mass (Fig. 3b), respectively. Clone LIM-6 had the lowest RS dry mass and had no RS stem dry mass on the SO sites. This indicates that clonal selection for greater RS might be effective for enhancing this desirable trait which is conducive to rapid site colonization on highly disturbed sites and stream banks susceptible to water erosion.

In general, there were no significant differences among INT clones in terms of coppice stem number between the two site types. However, clone LAF-2 produced a significantly greater coppice stem number on SO sites, whereas clones LIM-6 and PEM-4 produced significantly greater coppice stem numbers on GD sites. This finding points to the possibility of clonal selection for this trait (Fig. 4a). Root sprout stem number associated with coppiced plants was significantly greater on GD sites, a difference that was consistent for each of the eight clones tested (Fig. 4b). Mean coppice stem height and stem basal diameter in coppiced plants were always greater on SO sites, possibly due to higher nutrient levels $(\mathrm{C}, \mathrm{N}$, and $\mathrm{P})$.

\section{Conclusions}

To quantify biomass production in INT, it was necessary to distinguish between the ortet and associated RS to elucidate differences in the partitioning of growth and biomass production on different site types. Although total biomass production was not significantly affected by site type despite major differences in soil fertility and structure between the two site types studied, there were significant differences in biomass partitioning between the ortets and associated RS. The ortets growing on the more fertile SO sites had significantly greater aboveground stem dry mass; however, RS stem dry mass associated with each ortet was significantly greater on sites with loose gravel deposits (GD sites). We also observed significant differences among the eight INT clones tested in terms of both the aboveground stem dry mass and the RS stem dry mass associated with each clone. These differences point to the possibility of carrying out clonal selection for both growth traits and for ability to adapt to sites of differing quality. These genetic differences in growth and root- sprouting capacity affect the ability of INT to rapidly colonize infertile and highly disturbed sites. These differences could be harnessed to select INT clones that could be useful on disturbed sites such as former mine sites where rapid revegetation is required to mitigate soil surface erosion and consequent deterioration of water quality. Finally, colony-forming willows such as INT eliminate the need for periodic plantation re-establishment, providing a cost advantage over conventional short-rotation coppice-based woody biomass plantations with species that do not continuously produce new stems via root sprouting.

\section{Acknowledgements}

We are grateful to Setsuko Mosseler for assistance with fieldtest establishment and data collection, to Michel Labrecque and the Montreal Botanical Garden for hosting our willow commongarden collections, which provided plant material for the study, to the Canadian Forest Service for providing operating funds and facilities, and to Jim Estey of the University of New Brunswick's Laboratory for Forest Soils and Environmental Quality for conducting soil analyses.

\section{References}

Acton, P.M., Fox, J.F., Campbell, J.E., Jones, A.L., Rowe, H., Martin, D., and Bryson, S. 2011. Role of soil health in maintaining environmental sustainability of surface coal mining. Environ. Sci. Technol. 45: 10265-10272. doi:10.1021/es202764q. PMID:22029408.

Argus, G.W. 2007. Salix (Salicaceae) distribution maps and a synopsis of their classification in North America, north of Mexico. Harvard Papers in Botany, 12(7): 335-368. doi:10.3100/1043-4534(2007)12[335:SSDMAA]2.0.CO;2.

Argus, G.W. 2010. Salix L. In Flora of North America North of Mexico, Volume 7. Magnoliophyta: Salicaceae to Brassicaceae. Edited by Flora of North America Editorial Committee. Oxford University Press, Oxford and New York. pp. 23-162.

Barnes, W.J. 1985. Population dynamics of woody plants on a river island. Can. J. Bot. 63(3): 647-665. doi:10.1139/b85-081.

Bond, W.J., and Midgley, J.J. 2003. The evolutionary ecology of sprouting in woody plants. Intern. J. P1. Sci. 164: S103-S114. doi:10.1086/374191.

Bosela, M.J., and Ewers, F.W. 1997. The mode of origin of root buds and root sprouts in the clonal tree Sassafras albidum (Lauraceae). Am. J. Bot. 84: 1466-1481. doi:10.2307/2446609. PMID:21708553.

Caplan, T.R., Cothern, K., Landers, C., and Hummel, O.C. 2013. Growth response of coyote willow (Salix exigua) cuttings in relation to alluvial soil texture and water availability. Restor. Ecol. 21: 627-638. doi:10.1111/j.1526100X.2012.00928.X

Ceulemans, R., McDonald, A.J.S., and Pereira, J.S. 1996. A comparison among eucalypt, poplar and willow characteristic with particular reference to a coppice growth modelling approach. Biomass Bioenergy, 11: 215-231. doi:10.1016/0961-9534(96)00035-9.

Del Tredici, P. 2001. Sprouting in temperate trees: a morphological and ecological review. Bot. Rev. 67: 121-140. doi:10.1007/BF02858075.

Dimitriou, I., Mola-Yudego, B., Aronsson, P., and Eriksson, J. 2012. Changes in organic carbon and trace elements in the soil of willow short-rotation coppice plantations. Bioenerg. Res. 5: 563-572. doi:10.1007/s12155-0129215-1.

Dixon, M.D. 2003. Effects of flow pattern on riparian seedling recruitment on sandbars in the Wisconsin River, Wisconsin, U.S.A. Wetlands, 23: 125139. doi:10.1672/0277-5212(2003)023[0125:EOFPOR]2.0.CO;2.

Dorn, R.D. 1976. A synopsis of American Salix. Can. J. Bot. 54(24): 2769-2789. doi:10.1139/b76-297.

Dorn, R.D. 1998. A taxonomic study of Salix section Longifoliae (Salicaceae). Brittonia, 50: 193-210. doi:10.2307/2807852.

Doty, S.L., Oakley, B., Xin, G., Kang, J.W., Singleton, G., Khan, Z., et al. 2009. Diazotrophic endophytes of native black cottonwood and willow. Symbiosis, 47: 23-33. doi:10.1007/BF03179967.

Douhovnikoff, V., McBride, J.R., and Dodd, R.S. 2005. Salix exigua clonal growth and population dynamics in relation to disturbance regime variation. Ecology, 86: 446-452. doi:10.1890/04-0257.

Dowarah, J., Deka-Boruah, H.P., Gogoi, J., Pathak, N., Saikia, N., and Handique, A.K. 2009. Eco-restoration of a high-sulphur coal mine overburden dumping site in northern India: a case study. J. Earth Syst. Sci. 118: 597-608. doi:10.1007/s12040-009-0042-5.

Grady, K.C., Ferrier, S.M., Kolb, T.E., Hart, S.C., Allan, G.J., and Whitham, T.G. 2011. Genetic variation in productivity of foundation riparian species at the edge of their distribution: implications for restoration and assisted migration in a warming climate. Glob. Change Biol. 17: 3724-3735. doi:10.1111/j.13652486.2011.02524.x. 
Guerrero-Campo, J., Palacio, S.A.R.A., Pérez-Rontomé, C., and Montserrat-Martí, G. 2006. Effect of root system morphology on root sprouting and shoot rooting abilities in 123 plant species from eroded lands in northeast Spain. Ann. Bot. 98: 439-447. doi:10.1093/aob/mcl122. PMID:16790468.

Hansen, E.A. 1993. Soil carbon sequestration beneath hybrid poplar plantations in the North Central United States. Biomass Bioenergy, 5: 431-436. doi:10.1016/0961-9534(93)90038-6.

Hansen, E.A., McLaughlin, R.A., and Pope, P.E. 1988. Biomass and nitrogen dynamics of hybrid poplar on two different soils: implications for fertilization strategy. Can. J. For. Res. 18(2): 223-230. doi:10.1139/x88-033.

Heller, M.C., Keoleian, G.A., and Volk, T.A. 2003. Life cycle assessment of a willows bioenergy cropping system. Biomass Bioenergy, 25: 147-165. doi:10.1016/S0961-9534(02)00190-3.

Hicks, C.R. 1982. Fundamental concepts in the design of experiments. Holt, Rinehart and Winston, New York.

Hinds, H.R. 2000. Flora of New Brunswick. University of New Brunswick.

Hosner, J.F., and Minckler, L.S. 1963. Bottomland hardwood forests of southern Illinois: regeneration and succession. Ecology, 44: 29-41. doi:10.2307| 1933178.

Hossner, L.R., and Hons, F.M. 1992. Reclamation of mine tailings. Adv. Soil Sci. 17: 311-350. doi:10.1007/978-1-4612-2820-2 10.

Jug, A., Hofmann-Schielle, C., Makeschin, F., and Rehfuess, K.E. 1999. Shortrotation plantations of balsam poplar, aspen and willows on former arable land in the Federal Republic of Germany III. Soil ecological effects. For. Ecol. Manage. 121: 85-99. doi:10.1016/S0378-1127(98)00558-1.

Kammesheidt, L. 1999. Forest recovery by root suckers and aboveground sprouts after slash-and-burn agriculture, fire and logging in Paraguay and Venezuela. J. Trop. Ecol. 15: 143-157. doi:10.1017/S0266467499000723.

Kemperman, J.A., and Barnes, B.V. 1976. Clone size in American aspens. Can. J. Bot. 54(22): 2603-2607. doi:10.1139/b76-280.

Knoth, J.L., Kim, S.-H., Ettl, G.J., and Doty, S.L. 2014. Biological nitrogen fixation and biomass accumulation within poplar clones as a result of inoculation with diazotrophic consortia. New Phytol. 201: 599-609. doi:10.1111/ nph.12536. PMID:24117518.

Krasny, W.E., Vogt, K.A., and Zasada, J.C. 1988a. Adventitious rooting of four Salicaceae species in response to a flooding event. Can. J. Bot. 66(12): 2597-2598. doi:10.1139/b88-352.

Krasny, W.E., Zasada, J.C., and Vogt, K.A. 1988b. Establishment of four Salicaceae species on river bars in interior Alaska. Holarctic Ecol. 11: 210-219. doi:10.1111/ j.1600-0587.1988.tb00803.x.

Labrecque, M., and Teodorescu, T.I. 2005. Field performance and biomass production of 12 willow and poplars in short-rotation coppice in southern Quebec (Canada). Biomass Bioenergy, 29: 1-9. doi:10.1016/j.biombioe.2004.12. 004.

McLeod, K.W., Reed, M.R., and Nelson, E.A. 2001. Influence of a willow canopy on tree seedling establishment for wetland restoration. Wetlands, 21: 395-402. doi:10.1672/0277-5212(2001)021[0395:IOAWCO]2.0.CO;2.

Mirck, J., and Schroeder, W. 2013. Composition, stand structure, and biomass estimates of "willow rings" on the Canadian prairies. Bioenerg. Res. 6: 864-876. doi:10.1007/s12155-013-9338-z.

Mitton, J.B., and Grant, M.C. 1996. Genetic variation and the natural history of quaking aspen. BioScience, 46: 25-31. doi:10.2307/1312652.

Mosseler, A., and Major, J.E. 2015. Biomass and root stem production of a colony-forming willow (Salix interior) on highly disturbed, low fertility sites. Biomass Bioenergy, 74: 202-212. doi:10.1016/j.biombioe.2015.01.019.

Mosseler, A., Major, J.E., and Labrecque, M. 2014a. Growth and survival of seven native willow species on highly disturbed coal mine sites in eastern Canada. Can. J. For. Res. 44(4): 340-349. doi:10.1139/cjfr-2013-0447.

Mosseler, A., Major, J.E., Labrecque, M., and Larocque, G.R. 2014b. Allometric relationships in coppice biomass production for two North American willows (Salix spp.) across three different sites. For. Ecol. Manage. 320: 190196. doi:10.1016/j.foreco.2014.02.027.

Mosseler, A., Major, J.E., and Larocque, G.R. 2016. Allometric relationships from coppice structure of seven North American willow (Salix) species. Biomass Bioenergy, 88: 97-105. doi:10.1016/j.biombioe.2016.03.025.

Mosseler, A., and Major, J.E. 2017. Phytoremediation efficacy of Salix discolor and $S$. eriocephela on adjacent acidic clay and shale overburden on a former mine site: growth, soil and foliage traits. Forests, 8(12): 475. doi:10.3390/f8120475

Mosseler, A., Major, J.E., and McPhee, D. 2019. Bur oak (Quercus macrocarpa) biomass production on a former coal mine site: positive effects of coppicing on rapid recovery of growth and yield. Can. J. For. Res. 49(9): 10601068. doi:10.1139/cjfr-2019-0062.
Mosseler, A., Major, J.E., Ostaff, D., and Ascher, J. 2020. Bee foraging preferences on three willow (Salix) species: effects of species, plant sex, sampling day and time of day. Ann. Appl. Biol. 177: 333-345. doi:10.1111/ aab.12621.

Noble, M.G. 1979. The origin of Populus deltoides and Salix interior zones on point bars along the Minnesota River. Am. Midl. Nat. 102: 59-67. doi:10.2307| 2425066.

Ottenbreit, K.A., and Staniforth, R.J. 1992. Life cycle and age structure of ramets in an expanding population of Salix exigua (sandbar willow). Can. J. Bot. 70(6): 1141-1146. doi:10.1139/b92-141.

Pedrol, N., Puig, C.G., Souza, P., Forjan, R., Vega, F.A., Asensio, V., et al. 2010. Soil fertility and spontaneous revegetation in lignite spoil banks under different amendments. Soil Tillage Res. 110: 134-142. doi:10.1016/j. still.2010.07.005.

Rodrigues, R.R., Torres, R.B., Matthes, L.A.F., and Penha, A.S. 2004. Tree species sprouting from root buds in a semideciduous forest affected by fires. Braz. Arch. Biol. Technol. 47: 127-133. doi:10.1590/S1516-89132004000100017.

Saha, S., and Howe, H.F. 2003. Species composition and fire in a dry deciduous forest. Ecology, 84: 3118-3123. doi:10.1890/02-3051.

Sakai, A., Sakai, S., and Akiyama, F. 1997. Do sprouting tree species on erosion-prone sites carry large reserves of resources? Ann. Bot. 79: 625-630. doi:10.1006/anbo.1996.0389.

Savoie, P., Lavoie, F., and D'Amours, L. 2009. Development of two headers for a versatile woody brush harvester-baler. Appl. Eng. Agric. 25: 811-817. doi:10.13031/2013.29230.

Savoie, P., Hebert, P.-L., and Robert, F.-S. 2013. Harvest of short-rotation woody crops with small to medium size forage harvesters. In Proceedings of the American Society of Agricultural and Biological Engineers' Annual International Meeting, Kansas City, Mo., 21-24 July 2013. ASABE Paper 131620174. American Society of Agricultural and Biological Engineers (ASABE), St. Joseph, Mich. p. 14

Schrama, M., Vandecasteele, B., Carvalho, S., Muylle, H., and Van Der Putten, W.H. 2016. Effects of first- and second-generation bioenergy crops on soil processes and legacy effects on a subsequent crop. Bioenergy, 8: 136-147. doi:10.1111/ gcbb.12236.

Sixto, H., Salvia, J., Barrio, M., Pilar-Ciria, M., and Canellas, I. 2011. Genetic variation and genotype-environment interactions in short-rotation Populus plantations in southern, Europe. New For. 42: 163-177. doi:10.1007/s11056-010-9244-6.

Smith, S.D., Devitt, D.A., Sala, A., Cleverly, J.R., and Busch, D.E. 1998. Water relations of riparian plants from warm desert regions. Wetlands, 18: 687-696. doi:10.1007/BF03161683.

Snyder, K.A., and Williams, D.G. 2000. Water sources used by riparian trees varies among stream types on the San Pedro River, Arizona. Agric. For. Meteor. 105: 227-240. doi:10.1016/S0168-1923(00)00193-3.

Stella, J.C., and Battles, J.J. 2010. How do riparian woody seedlings survive seasonal drought? Oecologia, 164: 579-590. doi:10.1007/s00442-010-1657-6. PMID:20480183.

van Breugel, M., Ransijn, J., Craven, D., Bongers, F., and Hall, J.S. 2011. Estimating carbon stock in secondary forests: Decisions and uncertainties associated with allometric biomass models. For. Ecol. Manage. 262: 16481657. doi:10.1016/j.foreco.2011.07.018.

Van Cleve, K., Viereck, L.A., and Dyrness, C.T. 1996. State factor control of soils and forest succession along the Tanana River in interior Alaska, U.S. A. Arctic Alpine Res. 28: 388-400. doi:10.2307/1552118.

Vesk, P.A., and Westoby, M. 2004. Sprouting ability across diverse disturbances and vegetation types worldwide. J. Ecol. 92: 310-320. doi:10.1111/ j.0022-0477.2004.00871.x.

Walker, L.R., Zasada, J.C., and Chapin, F.S. 1986. The role of life history processes in primary succession of an Alaskan floodplain. Ecology, 67: 12431253. doi:10.2307/1938680.

Wiehle, M., Eusemann, P., Thevs, N., and Schnittler, M. 2009. Root suckering patterns in Populus euphratica (Euphrates poplar, Salicaceae). Trees, 23: 991-1001. doi:10.1007/s00468-009-0341-0.

Wong, M.H. 2003. Ecological restoration of mine degraded soils, with emphasis on metal contaminated soils. Chemosphere, 50: 775-780. doi:10.1016/S00456535(02)00232-1. PMID:12688490.

Zasada, D.A., Douglas, D.A., and Buechler, W. 2008. Salix L. willow. In The woody plant seed manual. Edited by F.T. Bonner and R.P. Karrfalt. Agriculture Handbook 727. USDA, Forest Service. pp. 1000-1009.

Zipper, C.E., Burger, J.A., Skousen, J.G., Angel, P.N., Barton, C.D., Davis, V., and Franklin, J.A. 2011. Restoring forests and associated ecosystem services on Appalachian coal surface mines. Environ. Manage. 47: 751-765. doi:10.1007/s00267-011-9670-z. PMID:21479921. 